\title{
Initial Assessment of Mean Arterial Pressure (MAP) for the Outcome of Head Injury Patients at Emergency Department in General Hospital of Ulin Banjarmasin
}

\author{
Laila Agustina $^{1}$, Siti Marhamah ${ }^{1}$, Musyarrofah $^{1}$, Desyka Yuniarti ${ }^{1}$, Larasati $^{1}$, Riky Teguh \\ Arifiannoor ${ }^{1}$, Muhammad Fadli ${ }^{2}$, Abdurahman Wahid ${ }^{3}$, Bagus Rahmat Santoso ${ }^{4}$ \\ $\left\{\right.$ laila.agustina23@gmail.com ${ }^{1}$, marhammm@gmail.com ${ }^{1}$, musyarrofah.a@gmail.com ${ }^{1}$, \\ desyka28@gmail.com ${ }^{1}$, larasati2532@gmail.com ${ }^{1}$, rikyteguh4@gmail.com ${ }^{1}$, \\ muhammadfadli006@gmail.com ${ }^{2}$, ns.wahid@unlam.ac.í ${ }^{3 *}, \underline{\text { ners_b4gs@yahoo.com }}^{4}$ \} \\ ${ }^{1}$ School of Nursing, Faculty of Medicine, University of Lambung Mangkurat, Indonesia \\ ${ }^{2}$ Department of Emergency, General Hospital of Ulin Banjarmasin, Indonesia \\ ${ }^{3}$ Department of Emergency Nursing, School of Nursing, Faculty of Medicine, University of Lambung \\ Mangkurat, Indonesia \\ ${ }^{4}$ Department of Emergency Nursing, School of Nursing, Faculty of Health, University of Sari Mulia, \\ Indonesia \\ *ns.wahid@unlam.ac.id
}

\begin{abstract}
There were 162 cases of head injury from January to March 2019, the highest presentation was mild head injury (63\%). Head injury is the top 10 cases of surgery for this current time. MAP is a compensation mechanism to maintain the pressure of cerebral perfusion. If the blood flow from the systemic circulation $>100 \mathrm{mmHg}$ it would potentially increase the ICP and if the blood flow $<60 \mathrm{mmHg}$ it would bring hypoxia, loss of consciousness, and the death of brain cells. This study aimed to determine the outcome of head injury patients by the initial assessment of MAP at emergency department in General Hospital of Ulin Banjarmasin. The research was conducted from March $4^{\text {th }}, 2019$ until April $21^{\text {st }}, 2019$ with observation sheet, the method used in this study was a descriptive explorative analytic observational with accidental sampling technique for 51 patients of head injury at emergency department in General Hospital of Ulin Banjarmasin. The results showed that the mean value of MAP was 93.33 $\mathrm{mmHg}$ for the lived and died head injury respondents.
\end{abstract}

Keyword: MAP, head injury, outcome

\section{Introduction}

There are many causes of head injury in children and adults in developing countries. The most common head injuries are from motor vehicle accidents (Oyedele et al, 2015). Based on study at ED in General Hospital of Ulin Banjarmasin there were 162 cases of head injuries from January to March 2019 and it is included in the top 10 most surgical disease cases at ED in General Hospital of Ulin Banjarmasin during that period. The mild head injury found 102 $(63 \%)$ cases, moderate head injury was about $31(19 \%)$ cases and severe head injury was 29 (18\%).

Mean arterial pressure (MAP) is a compensatory mechanism to maintain the cerebral perfusion pressure by increasing the MAP value. The greatest risk for irreversible brain damage and death would happen due to the failure of early identification and recognition the signs and symptoms of cerebral perfusion pressure and the adequacy of the mean arterial patients with head injury. (Guyton, Hall JE, 2007). 
Research by Martono et al, 2016 shown that there is a positive effect on the value of MAP with the level of consciousness, it is $77,8 \%$ able to detect the level of consciousness of head injury patients. Increasing the MAP value more than $65 \mathrm{mmHg}$ can improve the microcirculation and autoregulation of the brain, thus preventing the loss of consciousness for head injury patients. The objectives of this study is to identify the outcome of head injury patients by doing the initial assessment of MAP value at ED.

\section{Methods}

The research used a descriptive explorative analytic observational method with accidental sampling technique for 51 patients of head injury at Emergency Department in General Hospital of Ulin Banjarmasin. The research was conducted from March $4^{\text {th }}, 2019$ until April $21^{\text {st }} 2019$ with observation sheet.

\section{Result}

\section{Characteristics of Responden}

Age

Table 1: Respondents age characteristics

\begin{tabular}{ccccccc}
\hline \multirow{2}{*}{ Variabel } & \multirow{2}{*}{ N } & \multirow{2}{*}{ Mean } & \multirow{2}{*}{ Median } & \multirow{2}{*}{ SD } & \multicolumn{2}{c}{ CI 95\% } \\
\cline { 6 - 7 } & & & & Upper & Lower \\
\hline Age (year) & 51 & 37,51 & 31,00 & 19,643 & 74 & 7 \\
\hline Source : Primary data processed & & & & &
\end{tabular}

The average age of head injury patients who has arrived at Emergency Department in General Hospital of Ulin Banjarmasin was 37,51 years old, this data collected from 51 respondents. The data showed on table 1

\section{Gender}

Table 2: Respondents gender characteristics

\begin{tabular}{clccc}
\hline No & Gender & N & \% \\
\hline 1 & Male & 34 & $66,7 \%$ \\
2 & Female & 17 & $33,3 \%$ \\
\hline \multicolumn{2}{l}{ Total } & & 51 & $100 \%$ \\
\hline
\end{tabular}

Source : Primary data processed

Male respondents were the highest number in this study, it showed on table 2 that $66,7 \%$ (34 respondents) were male who has head injury. 


\section{Referral or Non Referral Patients}

Table 3: Delivered and non delivered patients

\begin{tabular}{clcc}
\hline No & Referral and Non Referral Patients & N & \% \\
\hline 1 & Referral & 28 & $54,9 \%$ \\
2 & Non Referral & 23 & $45,1 \%$ \\
\hline Total & 51 & $100 \%$ \\
\hline
\end{tabular}

Source : Primary data processed

There were $54,9 \%$ head injury respondents who were referral from another hospital to Emergency Department in General Hospital of Ulin Banjarmasin and just 45,1\% who has arrived at ED directly after got the accident. It showed on table 3.

\section{GCS Level}

Table 4: Respondents GCS Level characteristic

\begin{tabular}{clccc}
\hline No & \multicolumn{1}{c}{ GCS } & $\mathbf{N}$ & \% \\
\hline 1 & 13-15 (Mild head injury) & 12 & $23,5 \%$ \\
2 & $9-12$ (Moderate head injury) & 16 & $31,4 \%$ \\
3 & $3-8$ (Severe head injury) & 23 & $45,1 \%$ \\
\hline \multicolumn{2}{l}{ Total } & 51 & $100 \%$ \\
\hline
\end{tabular}

Source: Primary data processed

In this study, respondents mostly got severe head injury. Based on the GCS level, from 51 respondents there were 23 respondents $(45,1 \%)$ who has 3-8 GCS score. It showed on table 4.

\section{Respondents Characteristic with Mild Head Injury} Systolic Blood Pressure

Table 5: Systolic Blood Pressure in Mild Head Injury Respondents

\begin{tabular}{ccccccc}
\hline Variabel & \multirow{2}{*}{ N } & \multirow{2}{*}{ Mean } & \multirow{2}{*}{ Median } & \multirow{2}{*}{ SD } & \multicolumn{2}{c}{ CI 95\% } \\
\cline { 6 - 7 } & & & & & Upper & Lower \\
\hline Systolic Blood Pressure & 12 & 127,67 & 125,00 & 21,740 & 172 & 100 \\
\hline Source: Primary data processed & & &
\end{tabular}

Source: Primary data processed

Table 5 showed that the mean score of systolic blood pressure from 12 respondents who had mild head injury was $127,67 \mathrm{mmHg}$.

\section{Diastolic Blood Pressure}

Table 6: Diastolic Blood Pressure in Mild Head Injury Respondents

\begin{tabular}{ccccccc}
\hline Variabel & \multirow{2}{*}{ N } & \multirow{2}{*}{ Mean } & \multirow{2}{*}{ Median } & \multirow{2}{*}{ SD } & \multicolumn{2}{c}{ CI 95\% } \\
\cline { 5 - 7 } & & & & & Upper & Lower \\
\hline Diastolic Blood Pressure & 12 & 81,00 & 80,00 & 9,964 & 100 & 60 \\
\hline
\end{tabular}

Source: Primary data processed

Diastolic blood pressure score from 12 respondents who had mild head injury was $81,00 \mathrm{mmHg}$, it showed on table 6 . 


\section{Outcome with Mild Head Injury}

Table 7: Mild Head Injury Outcome

\begin{tabular}{cccc}
\hline No & Outcome & N & \% \\
\hline 1 & Lived & 10 & $83,3 \%$ \\
2 & Died & 2 & $16,7 \%$ \\
\hline \multicolumn{2}{c}{ Total } & 12 & $100 \%$ \\
\hline
\end{tabular}

Source: Primary data processed

From the data who has collected and analyzed shown that the mortality score from 12 respondents who got mild head injury were low.

\section{Mean Arterial Pressure (MAP) Score}

Table 8: MAP Score in Mild Head Injury Respondents

\begin{tabular}{llcc}
\hline No & \multicolumn{1}{c}{ MAP } & N & \% \\
\hline 1 & $<93,33 \mathrm{mmHg}$ & 5 & $41,7 \%$ \\
2 & $93,33-99,00 \mathrm{mmHg}$ & 2 & $16,7 \%$ \\
3 & $>99,00$ & 5 & $41,7 \%$ \\
\hline \multicolumn{2}{c}{ Total } & 12 & $100 \%$ \\
\hline
\end{tabular}

Source: Primary data processed

Mean arterial pressure in mild head injury respondents were <93,33 $\mathrm{mmHg}(41,7 \%)$, $93,33-99,00 \mathrm{mmHg}(16,7 \%)$, and $>99,00 \mathrm{mmHg}(41,7 \%)$, it had been analyzed from 12 respondents.

Table 9: MAP Score in Lived Mild Head Injury Respondents

\begin{tabular}{ccccccc}
\hline \multirow{2}{*}{ Variabel } & \multirow{2}{*}{ Mean } & \multirow{2}{*}{ Median } & \multirow{2}{*}{ SD } & \multicolumn{2}{c}{ CI 95\% } \\
\cline { 5 - 7 } & & & & Upper & Lower \\
\hline MAP & 10 & 96,44 & 96,60 & 12,129 & 113 & 73 \\
\hline Source: Primary data processed & & &
\end{tabular}

Table 10: MAP Score in Died Mild Head Injury Respondents

\begin{tabular}{ccccccc}
\hline \multirow{2}{*}{ Variabel } & \multirow{2}{*}{ N } & \multirow{2}{*}{ Mean } & \multirow{2}{*}{ Median } & \multirow{2}{*}{ SD } & \multicolumn{2}{c}{ CI 95\% } \\
\cline { 6 - 7 } & & & & & Upper & Lower \\
\hline MAP & 2 & 97,00 & 97,00 & 14,142 & 107 & 87 \\
\hline
\end{tabular}

Source: Primary data processed

There were 10 respondents lived from mild head injury with the mean value of MAP Score 96,44 mmHg (table 9), meanwhile there were 2 respondents who died got 97,00 $\mathrm{mmHg}$ as the mean value of MAP Score (table 10). 
Respondents Characteristic with Moderate Head Injury Systolic Blood Pressure

Table 11: Systolic Blood Pressure in Moderate Head Injury Respondents

\begin{tabular}{lcccccc}
\hline Variabel & \multirow{2}{*}{ N } & \multirow{2}{*}{ Mean } & \multirow{2}{*}{ Median } & \multirow{2}{*}{ SD } & \multicolumn{2}{c}{ CI 95\% } \\
\cline { 5 - 7 } & & & & Upper & Lower \\
\hline Systolic Blood Pressure & 16 & 121,75 & 115,00 & 25,953 & 180 & 90 \\
\hline Source: Primary data processed & & & &
\end{tabular}

There were 16 respondents who got moderate head injury with the mean score of systolic blood pressure was $121,75 \mathrm{mmHg}$ (table 11 ).

\section{Diastolic Blood Pressure}

Table 12: Diastolic Blood Pressure in Moderate Head Injury Respondents

\begin{tabular}{lllllll}
\hline \multirow{2}{*}{ Variabel } & \multirow{2}{*}{ N } & \multirow{2}{*}{ Mean } & \multirow{2}{*}{ Median } & \multirow{2}{*}{ SD } & \multicolumn{2}{c}{ CI 95\% } \\
\cline { 5 - 7 } & & & & Upper & Lower \\
\hline Diastolic Blood Pressure & 16 & 73,63 & 74,50 & 12,521 & 100 & 50 \\
\hline
\end{tabular}

Source: Primary data processed

Based on table 12, there were 16 respondents who got moderate head injury respondents had 73,63 $\mathrm{mmHg}$ diastolic blood pressure.

\section{Outcome with Moderate Head Injury}

Table 13: Moderate Head Injury Outcome

\begin{tabular}{clccc}
\hline No & & Outcome & N & \% \\
\hline 1 & Lived & 9 & $56,3 \%$ \\
2 & Died & 7 & $43,7 \%$ \\
\hline \multicolumn{2}{l}{ Total } & & 16 & $100 \%$ \\
\hline
\end{tabular}

Source: Primary data processed

Respondents with moderate head injury mostly got lower mortality score $(43,7 \%)$ and there $56,3 \%$ respondents were lived.

\section{Mean Arterial Pressure (MAP) Score}

Table 14: MAP Score in Moderate Head Injury Respondents

\begin{tabular}{clcc}
\hline No & MAP & $\mathbf{N}$ & \% \\
\hline 1 & $<93,33 \mathrm{mmHg}$ & 10 & $62,5 \%$ \\
2 & $93,33-99,00 \mathrm{mmHg}$ & 1 & $6,2 \%$ \\
3 & $>99,00$ & 5 & $31,3 \%$ \\
\hline \multicolumn{2}{l}{ Total } & 16 & $100 \%$ \\
\hline
\end{tabular}

Source: Primary data processed

The persentation of highest MAP score in 16 respondents with moderate head injury were $<93,33 \mathrm{mmHg}(62,5 \%)$ (Table 14$)$ 
Table 15: MAP Score in Lived Moderate Head Injury Respondents

\begin{tabular}{ccccccc}
\hline \multirow{2}{*}{ Variabel } & \multirow{2}{*}{ N } & \multirow{2}{*}{ Mean } & Median & \multirow{2}{*}{ SD } & \multicolumn{2}{c}{ CI 95\% } \\
\cline { 5 - 7 } & & & & & Upper & Lower \\
\hline MAP & 9 & 86,91 & 86,00 & 13,759 & 106 & 63 \\
\hline
\end{tabular}

Source: Primary data processed

Table 16: MAP Score in Died Moderate Head Injury Respondents

\begin{tabular}{ccccccc}
\hline \multirow{2}{*}{ Variabel } & \multirow{2}{*}{ N } & \multirow{2}{*}{ Mean } & Median & SD & \multicolumn{2}{c}{ CI 95\% } \\
\cline { 5 - 7 } & 7 & 92,66 & 90,00 & 19,477 & 126 & 70 \\
\hline
\end{tabular}

Source: Primary data processed

From 16 respondents we found 9 respondents lived with the mean score of MAP was $86,91 \mathrm{mmHg}$ (table 15) and there were 7 respondents died with 92,66 $\mathrm{mmHg}$ (table 16).

\section{Respondents Characteristic with Severe Head Injury}

Systolic Blood Pressure

Table 17 : Systolic Blood Pressure in Severe Head Injury Respondents

\begin{tabular}{ccccccc}
\hline Variabel & \multirow{2}{*}{ N } & \multirow{2}{*}{ Mean } & \multirow{2}{*}{ Median } & \multirow{2}{*}{ SD } & \multicolumn{2}{c}{ CI 95\% } \\
\cline { 5 - 7 } & & & & Upper & Lower \\
\hline Systolic Blood Pressure & 23 & 130,74 & 130,00 & 34,784 & 203 & 80 \\
\hline Source: Primary data processed & & & & &
\end{tabular}

The mean score of systolic blood pressure in 23 severe head injury respondents was $130,74 \mathrm{mmHg}$, it showed on table 17.

Diastolic Blood Pressure

Table 5.18: Diastolic Blood Pressure in Severe Head Injury Respondents

\begin{tabular}{ccccccc}
\hline Variabel & \multirow{2}{*}{ N } & \multirow{2}{*}{ Mean } & \multirow{2}{*}{ Median } & \multirow{2}{*}{ SD } & \multicolumn{2}{c}{ CI 95\% } \\
\cline { 5 - 7 } & & & & Upper & Lower \\
\hline Diastolic Blood Pressure & 23 & 73,52 & 70,00 & 15,126 & 118 & 50 \\
\hline
\end{tabular}

Source: Primary data processed

Table 18 showed there were 23 respondents with severe head injury has 73,52 $\mathrm{mmHg}$ as the mean score of diastolic blood pressure.

Outcome with Severe Head Injury

Table 19: Severe Head Injury Outcome

\begin{tabular}{clccc}
\hline No & Outcome & N & \% \\
\hline 1 & Lived & 9 & $39,1 \%$ \\
2 & Died & 14 & $60,9 \%$ \\
\hline \multicolumn{2}{l}{ Total } & & 23 & $100 \%$ \\
\hline
\end{tabular}

Source: Primary data processed

Mortality presentation was the highest score in severe head injury respondents, it was analyzed from 23 respondents $(60,9 \%)$. 
Mean Arterial Pressure (MAP) Score

Table 20: MAP Score in Severe Head Injury Respondents

\begin{tabular}{clcc}
\hline No & \multicolumn{1}{c}{ MAP } & $\mathbf{N}$ & \% \\
\hline 1 & $<93,33 \mathrm{mmHg}$ & 15 & $65,2 \%$ \\
2 & $93,33-99,00 \mathrm{mmHg}$ & 1 & $4,3 \%$ \\
3 & $>99,00$ & 7 & $30,5 \%$ \\
\hline \multicolumn{2}{l}{ Total }
\end{tabular}

Source: Primary data processed

It has shown on table 20 that 23 respondents who had severe head injury mostly got $<93,33 \mathrm{mmHg}(65,2 \%)$ MAP score.

Table 21: MAP Score in Lived Severe Head Injury Respondents

\begin{tabular}{ccccccc}
\hline \multirow{2}{*}{ Variabel } & \multirow{2}{*}{ N } & \multirow{2}{*}{ Mean } & Median & \multirow{2}{*}{ SD } & \multicolumn{2}{c}{ CI 95\% } \\
\cline { 5 - 7 } & & & & & Upper & Lower \\
\hline MAP & 9 & 87,31 & 86,60 & 9,872 & 104 & 73 \\
\hline
\end{tabular}

Source: Primary data processed

Table 22: MAP Score in Died Severe Head Injury Respondents

\begin{tabular}{ccccccc}
\hline \multirow{2}{*}{ Variabel } & \multirow{2}{*}{$\mathbf{N}$} & \multirow{2}{*}{ Mean } & Median & \multirow{2}{*}{ SD } & \multicolumn{2}{c}{ CI 95\% } \\
\cline { 5 - 7 } & & & & Upper & Lower \\
\hline MAP & 14 & 95,77 & 90,15 & 21,976 & 128 & 60 \\
\hline
\end{tabular}

Source: Primary data processed

The mean score of MAP in 9 alive respondents were 87,31 mmHg (table 21). From 23 respondents there were 14 respondents with severe head injury who died with $95,77 \mathrm{mmHg}$ as the mean score of MAP (table 22).

\section{DISCUSSION}

\section{Characteristics of Respondents with Mild Head Injury}

This study was conducted on March $4^{\text {th }}, 2019$ to April 21 $1^{\text {st }}, 2019$ at Emergency department in General Hospital of Ulin Banjarmasin, there were 51 respondents with head injuries. This study divided into 3 groups based on the Glasgow Coma Scale (GCS) score, there were mild head injury, moderate head injury, and severe head injury.

Based on the results of this study, from 51 respondents there were 12 respondents suffered mild head injury (GCS 13-15) and there were 2 respondents of mild head injury were died. The data shown that the first respondent who died showed systolic blood pressure (SBP) was $100 \mathrm{mmHg}$ and diastolic blood pressure (DBP) $80 \mathrm{mmHg}$ with MAP $87 \mathrm{mmHg}$, respiration rate (RR) 24/min, heart rate 53/min, and temperature $35.6{ }^{0} \mathrm{C} /$ axilla with GCS score 13. Whereas in the second respondent those who died showed SBP/DBP 160/80 $\mathrm{mmHg}$ with MAP $107 \mathrm{mmHg}$, RR 26/min, pulse rate 53/min, and Temperature $36.4{ }^{\circ} \mathrm{C} / \mathrm{axilla}$ with GCS score 14.

MAP in head injury patients should be maintained at a minimum about $90 \mathrm{mmHg}$ so that the incidence of ischemia brain tissue can be avoided. The circulation should be maintained by fluids and inotropic drugs to maintain MAP in range $90 \mathrm{mmHg}$ [3]. The MAP value at $70-80 \mathrm{mmHg}$ is very possible to make a critical condition for patients. MAP is related 
to cerebral perfusion (CPP), the mortality patients would increases about $20 \%$ for every 10 $\mathrm{mmHg}$ reduction in CPP. So if we could maintain the CPP above $70 \mathrm{mmHg}$ can reduce the mortality of head injury patients about $35 \%$.

The study of Tjahjadi, also showed that the decrease of blood pressure, MAP value, and temperature will cause brain tissue ischemia and also another secondary effects. Cushing's response (arterial hypertension, bradycardia, and irregular breathing) has important clinical implications, where Intracranial Pressure (ICP) can shows some disproportionate and uncontrollable damage. $97,17 \mathrm{mmHg}$ was a good limit value of MAP and it was also gave a good outcome for the respondents based on Tjahjadi's study (2013) [4].

Based on this study and the previous studies, it can be concluded that maintaining MAP value between 93,33-99,00 $\mathrm{mmHg}$ can improve the outcome of patients with head injuries. Meanwhile, in addition for MAP value in mild head injury patients who was the outcome obtained died, we found another several factors that exacerbate patient outcomes. The first respondent who died experiencing active bleeding on the head and also the Hb value of patient had decreased, even though unsignificantly $(13.8 \mathrm{~g} / \mathrm{dl})$. Further data found that the second respondent whod died with mild head injury due to the indication of shock that caused by multiple trauma and active bleeding that came out from the nose and the catheter tube. The patient's $\mathrm{Hb}$ also decreased significantly at $6.6 \mathrm{~g} / \mathrm{dl}$.

\section{Characteristics of Respondents with Moderate Head Injury}

We obtained 16 respondents with moderate head injury based on the results of this study, 7 respondents died with the mean value of arterial pressure $93 \mathrm{mmHg}$, from those 7 respondents who died there were 4 people with the mean value of arterial pressure were less than $93 \mathrm{mmHg}$, another 2 respondents were more than $99 \mathrm{mmHg}$ and 1 respondent was in the range between 93 to $99 \mathrm{mmHg}$. Based on the research of A Guha (2015), the circulation of patients with head injuries are maintained by fluid with the mean value of arterial pressure at $90 \mathrm{mmHg}$, it happens to maintain a stable supply of oxygen and perfusion through the blood flow to the brain to avoid the brain damage [3]. The other article who has written by Martono (2016) mentioned that if the blood flow from the systemic circulation needed to provide adequate oxygen and glucose for metabolism in the brain is more than $100 \mathrm{mmHg}$, then it would potentially increase the ICP and if the blood flow less than $60 \mathrm{mmHg}$ it would bring hypoxia, loss of consciousness, and the death of brain cells [5]. For those reason, it is very important to maintain a stable supply of cerebral blood flow to prevent further damage. By to know the MAP value is one of ways to assess the perfusion pressure of organs in the body. MAP value $>60 \mathrm{mmHg}$ is enough to maintain perfusion and oxygen for organs throughout the body. If MAP decrease significantly lees than $60 \mathrm{mmHg}$ for a long period, blood flow will not be sufficient for the body's organs and will become ischemic [6].

\section{Characteristics of Respondents with Severe Head Injury}

There were 23 respondents with severe head injury from 51 respondents and there were 14 respondents died from those 23 respondents. The respondents with severe head injury had $130.74 \mathrm{mmHg}$ as a mean value of systolic pressure. Based on Tjahjadi's research in 2013, it showed that systolic blood pressure less than $90 \mathrm{mmHg}$ with hypoxia would result in poor outcomes. In patients with severe head injury will occur the decrease of blood pressure (systolic and diastolic) accompanied by the decrease of MAP and an increase of body temperature will cause ischemic in the brain cells and it would lead to another secondary effects. Based on the result of this study there were 9 respondents who lived from severe head injury with the mean value of MAP was $87.31 \mathrm{mmHg}$, and there were 14 respondents died 
with the mean value of MAP was $95.77 \mathrm{mmHg}$. From the study of Thahjadi in 2013 showed that a good MAP value for severe head injury patients was at $97.17 \mathrm{mmHg}$ [4].

\section{Conclusions}

MAP is defined as the mean pressure in a patient's arteries during one cardiac cycle. MAP can be used as representative variable for blood pressure instead of SBP and DBP separately. To perfuse vital organs requires the maintenance of a maximum MAP of 100 $\mathrm{mmHg}$, if MAP increase more than $100 \mathrm{mmHg}$, it could increase the intracranial pressure and MAP have to minimum of $60 \mathrm{mmHg}$. If MAP drops lower than this point for an extended period, end-organ manifestations such as ischemia and infarction can occur. If the MAP drops significantly, blood will not be able to perfuse cerebral tissues, there will be a loss of consciousness, and neuronal death will happen as soon. The MAP of the lived respondents from head injury in this study ranged between 86.91 to $96.44 \mathrm{mmHg}$. While the MAP of the head injury respondents who died was in the range of $92.66-97.00 \mathrm{mmHg}$. The outcomes in patients with head injuries should not only be based on MAP but other factors such as internal bleeding or comorbidities can be considered as well as the patient's initial condition of referral or non-referral. This is can illustrate or describe, not only the initial MAP of the patient that needs to be examined but also needs observe to other factors that can worsen the patient's condition. It is expected for further research to be able to observe to other matters that can affect the MAP value so that the outcame of head injury patients is more predictable.

\section{Research Limitations}

We only focused on the patient's first MAP upon arrival at the emergency department with the outcomes when the patient left the emergency department. The limitation in this study is that the researcher did not control for other factors that could worsen MAP in head injury patients such as active bleeding, multifunctional trauma and historical of the patient's illness, referral patients from other hospitals, the length of time the patient got a head injury until they arrived at hospitals and other factors that can maintain or improve MAP after arriving at Ulin Hospital such as drugs.

\section{References}

[1] Guyton, Hall JE. Buku Ajar Fisiologi Kedokteran (Terjemahan). EGC, Jakarta (2007)

[2] [2] Widyaswara, PA, Wihastuti TA, Fathoni M. Analisis Faktor-faktor yang Berhubungan dengan Outcome Pasien Cedera Kepala Di IGD RSUD Prof. Dr. Margono Soekardjo Purwokerto. Jurnal Ilmiah Kesehatan Keperawatan: Vol 12 no.3 pp 154-164 (2016)

[3] [3] Guha, A.: Management of traumatic brain injury: some current evidence and applications. Postgrad Med J. No: 80, pp: 650-653 (2004)

[4] [4] Tjahjadi, M, Muhammad Z.A, Arwinder S. G, dan Ahmad F.: Early mortality predictor of severe traumatic brain injury: a single center study of prognostic variables based on admission characteristics. The Indian Journal of Neurotrauma pp: 3-8 (2013)

[5] [5] Martono, et al : Deteksi dini derajat kesadaran menggunakan pengukuran nilai kritis mean artery pressure. Jurnal Ners Vol. 11 No. 1 pp 73-78 (2016)

[6] [6] Rabindra Nath Das. 2107. "The Mean Arterial Blood Pressure Determinants". EC Cardiology 4.1 pp 14-16 (2017) 